\title{
Cachectin/Tumor Necrosis Factor Regulates Hepatic Acute-phase Gene Expression
}

David H. Perlmutter, Charles A. Dinarello, Patricia I. Punsal, and Harvey R. Colten

Divisions of Gastroenterology, Nutrition and Cell Biology, Children's Hospital; and Department of Pediatrics, Harvard Medical School, Boston, Massachusetts 02115; Department of Experimental Medicine, Tufts University School of Medicine, Medford, Massachusetts 02155; Departments of Pediatrics, Cell Biology and Physiology, Washington University

School of Medicine and Children's Hospital, St. Louis, Missouri 63178

\section{Abstract}

The monokine, cachectin/tumor necrosis factor (TNF) differs from interleukin 1 (IL-1) in primary structure and in recognition by a distinct cellular receptor. It does, however, encode effector functions that are similar to those of IL-1 and characteristic of the host response to inflammation or tissue injury. Accordingly, we examined the possibility that recombinant-generated human TNF regulates hepatic acute-phase gene expression. In picomolar concentrations, TNF mediated reversible, dose- and time-dependent increases in biosynthesis of complement proteins factor B and C3, $\alpha_{1}$ antichymotrypsin, and decreases in biosynthesis of albumin and transferrin in human hepatoma cell lines (Hep G2, Hep 3B). Biosynthesis of complement proteins $\mathbf{C 2}$ and $\mathbf{C 4}$, and $\alpha_{1}$ proteinase inhibitor were not affected by TNF. TNF also increased factor $B$ gene expression, but had no effect on $\mathrm{C} 2$ gene expression, in murine fibroblasts transfected with cosmid DNA bearing the human $\mathrm{C} 2$ and factor $B$ genes. The effect of TNF on acute-phase protein expression ( $\mathrm{C3}$, factor $\mathrm{B}$, albumin) was pretranslational as shown by changes in specific messenger RNA content.

\section{Introduction}

The host response to acute inflammation, the acute-phase response, is characterized by a coordinated series of metabolic reactions involving different tissues and organ systems. Fever, leukocytosis, increased muscle proteolysis, alterations in carbohydrate, lipid, and trace mineral metabolism, and profound changes in the plasma concentrations of liver-derived plasma proteins occur. When the inflammatory process is prolonged, these changes in basal metabolism may result in chronic wasting, or cachexia.

In a variety of experimental systems it has now been shown that a monokine, interleukin 1 (IL-1), ${ }^{1}$ can elicit many of the metabolic reactions that constitute the acute-phase response (1,

Address correspondence to Dr. Perlmutter, Washington U. School of Medicine, St. Louis Children's Hospital, 400 S. Kingshighway Blvd., P.O. Box 14871, St. Louis, MO 63178.

Received for publication 12 May 1986.

1. Abbreviations used in this paper: $\mathrm{C} 2, \mathrm{C} 3$, and $\mathrm{C} 4$, second, third, and fourth components of complement, respectively; DME, Dulbecco's modified Eagle's medium; IL-1, interleukin 1; PAGE, polyacrylamide gel electrophoresis; PMSF, phenylmethylsulfonylfluoride.

J. Clin. Invest.

(C) The American Society for Clinical Investigation, Inc.

0021-9738/86/11/1349/06 \$1.00

Volume 78, November 1986, 1349-1354
2). We have recently shown that this monokine mediates changes in hepatic gene expression characteristic of the acute-phase response. IL-1 increased the expression of positive, acute-phase reactants, complement factor $B$, and the third component of complement (C3), and decreased the expression of negative acutephase reactant albumin in primary cultures of mouse hepatocytes (3) and human hepatoma cells (4). Furthermore, increases in expression of factor B were also elicited by IL-1 in murine fibroblast cell lines transfected with cosmid DNA bearing the human second component of complement (C2) and factor B genes (4).

Cachectin/tumor necrosis factor (TNF), another cytokine released by mononuclear phagocytes in response to lipopolysaccharide, elicits a complex repertoire of metabolic reactions during inflammation (5). This molecule was originally identified as a factor producing cachexia in experimental animals. It has since been shown to decrease the synthesis of anabolic enzymes in adipose tissue (6-8), and recently found to be identical to tumor necrosis factor, a monokine that produces hemorrhagic necrosis of tumors $(9,10)$. TNF has been cloned and its complete nucleotide sequence determined. The human TNF complementary DNA (cDNA) is 1,585 basepairs long, and encodes an $\sim 25-\mathrm{kD}$ precursor and a mature protein of $17.3 \mathrm{kD}(11,12)$. TNF is structurally distinct but shares several functional characteristics with IL-1. It produces fever in experimental animals (13), stimulates collagenase and prostaglandin $E_{2}$ production by human synovial cells and dermal fibroblasts (14), and augments the phagocytic activities of neutrophils (15). Moreover, IL-1 has been shown to elicit effector functions that were previously associated with TNF, including tumor cytostasis $(16,17)$ and suppression of lipoprotein lipase activity in adipocytes (18). Accordingly, we examined the possibility that TNF was similar to IL-1 in regulation of the expression of hepatic gene products that are affected during the acute-phase response.

\section{Methods}

\section{Materials}

Dulbecco's modified Eagle's medium (DME) and DME lacking methionine were purchased from Gibco, Grand Island, NY, and Hanks' balanced salt solution (HBSS) from Microbiological Assoc., Walkersville, MD. Fetal bovine serum, L-glutamine, and penicillin-streptomycin were from Flow Laboratories, Rockville, MD. $\left[{ }^{35}\right.$ S]Methionine (specific radioactivity $\sim 1,000 \mathrm{Ci} / \mathrm{mmol}$ ) and $\left[{ }^{32} \mathrm{P}\right]$ deoxycytidine triphosphate (specific radioactivity $\sim 3,000 \mathrm{Ci} / \mathrm{mmol}$ ) were obtained from New England Nuclear, Boston, MA, and $\left[{ }^{14} \mathrm{C}\right]$ methylated protein standards from Amersham Corp., Arlington Heights, IL. Other reagents included sodium deoxycholic acid, ethidium bromide, and 2-mercaptoethanol from Sigma Chemical Co., St. Louis, MO, Triton X-100 from Mallinckrodt Inc., St. Louis, MO, sodium dodecyl sulfate (SDS) and acrylamide from Bio-Rad Laboratories, IgG-Sorb from Enzyme Center, Cambridge, MA, leupeptin and pepstatin A from Peptide Research Institute, Osaka, Japan, cesium chloride from Bethesda Research Laboratories, Gaithersburg, MD, gua- 
nidine isothiocyanate from Fluka AG, Buchs, Switzerland, and sodium $N$-laurylsarcosinate from ICN Pharmaceuticals, Inc., Irvine, CA. Goat anti-human factor B, goat anti-human C3, goat anti-human C4, goat anti-human albumin were purchased from Atlantic Antibodies, Scarborough, ME, rabbit anti-human $\alpha_{1}$ proteinase inhibitor, rabbit antihuman $\alpha_{1}$ antichymotrypsin, rabbit anti-human inter- $\alpha$-trypsin inhibitor, rabbit anti-human $\alpha_{1}$ acid glycoprotein, and rabbit anti-human transferrin were purchased from Dako Corp., Santa Barbara, CA, and sheep anti-human C2 came from Seward Laboratories, London, England. Recombinant-generated human TNF was kindly provided by Genentech, South San Francisco, CA, and recombinant-generated human pI 7.0 IL1, R006B (24 kD), and R006T (17 kD) were provided by Cistron Technology (Pine Brook, NJ). These preparations contain $<80$ pg endotoxin/ mg protein (13). Recombinant-generated human pI 5.0 IL-1 was purchased from Genzyme, Boston, MA, and human monocyte IL-1 was purified by previously described methods $(4,19)$.

\section{Methods}

Cell culture and biosynthetic labeling. Confluent monolayers of Hep G2 and Hep 3B and murine fibroblast L cells transfected with cosmid DNA bearing the human $\mathrm{C} 2$ and factor $\mathrm{B}$ genes were maintained as previously described $(20,21)$. After incubation without or with a specified monokine, monolayers were rinsed three times with HBSS, and then incubated for $30 \mathrm{~min}$ at $37^{\circ} \mathrm{C}$ in DME lacking methionine but supplemented with $\left.{ }^{35} \mathrm{~S}\right]$ methionine, $250 \mu \mathrm{Ci} / \mathrm{ml}$. At the end of this labeling interval, culture medium was discarded, monolayers rinsed several times, and cells solubilized in phosphate-buffered saline (PBS) containing 1\% Triton X$100,0.5 \%$ deoxycholic acid, $10 \mathrm{mM}$ EDTA, $2 \mathrm{mM}$ phenylmethylsulfonylfluoride (PMSF), $100 \mu \mathrm{g} / \mathrm{ml}$ leupeptin, and pepstatin A, with two freezethaw cycles. Lysates were clarified by centrifugation at $15,000 \mathrm{~g}$ for 30 min and stored at $-70^{\circ} \mathrm{C}$. Trichloroacetic acid (TCA)-precipitable protein was determined as previously described (22).

Immunoprecipitation and SDS-polyacrylamide gel electrophoresis $(P A G E)$. Aliquots of cell lysate were incubated overnight at $4^{\circ} \mathrm{C}$ in $1 \%$ Triton X-100/1\% SDS/0.5\% deoxycholic acid, with excess antibody. Immune complexes were precipitated with excess formalin-fixed staphylococci-bearing protein A, washed, released by boiling in sample buffer, and applied to SDS-PAGE under reducing conditions as described by Laemmli (23). The equivalent of $5 \times 10^{4}-5 \times 10^{5}$ cells were used for each immunoprecipitate depending upon the relative abundance of the hepatic secretory protein being detected. $\left[{ }^{14} \mathrm{C}\right]$ Methylated molecular mass markers $(200,92.5,68,46$, and $30 \mathrm{kD})$ were included on all gels. After electrophoresis, gels were stained in Coomassie Brilliant Blue, destained, impregnated with 2,5-diphenyloxazole (En ${ }^{3}$ hance; New England Nuclear) and dried for fluorography on Kodak XAR x-ray film.

Incorporation of $\left.{ }^{35} S\right]$ methionine into individual immunoprecipitated proteins was determined in gel slices after digestion with $15 \%$ hydrogen peroxide for $16 \mathrm{~h}$ at $56^{\circ} \mathrm{C}$ and direct scintillation counting. Results are presented as mean values.

Detection of RNA by RNA blot analysis. Total cellular RNA was isolated from monolayers of hepatoma cells and $L$ cells by guanidine isothiocyanate extraction and ethanol precipitation (24). RNA was quantified by absorbance at $260 \mathrm{nM}$ and solubilized for agarose-formaldehyde gel electrophoresis and transfer to nitrocellulose filters (25). Filters were then hybridized with $\left[{ }^{32} \mathrm{P}\right]$ labeled $\mathrm{CDNA}$ probes for human factor B (26), C2 (27), C3 (28), and albumin (29). After hybridization, filters were washed extensively, dried, and exposed to x-ray film for autoradiography.

Densitometry was conducted on the Quick Scanner (Helena Laboratories, Beaumont, TX) equipped with an integrator.

\section{Results}

TNF increases the biosynthesis of several hepatic acute-phase proteins and decreases the biosynthesis of albumin and transferrin. Human hepatoma cells (Hep G2 and Hep 3B) were incubated in medium containing TNF or IL-1 for $18 \mathrm{~h}$, then bio- synthetically labeled for $30 \mathrm{~min}$. Several secretory proteins were detected in the intracellular lysates by immunoprecipitation, SDS-PAGE, and fluorography (Fig. 1). There was an increase in biosynthesis of factor B, C3, and $\alpha_{1}$ antichymotrypsin and a decrease in biosynthesis of albumin and transferrin in the presence of each monokine. The addition of IL-1 or TNF to hepatoma cells resulted in $\sim 2.5-3.0$-fold increases in synthesis of factor B, 2.0-2.5-fold increases in C3, and 2.0-2.5-fold decreases in synthesis of albumin and transferrin (Table I). Synthesis of $\alpha_{1}$ acid glycoprotein and inter- $\alpha$-trypsin inhibitor increased minimally in the presence of TNF or IL-1. There was no change in the synthesis of $\mathrm{C} 2$, the fourth component of complement (C4), $\alpha_{1}$ proteinase inhibitor, or total TCA-precipitable protein. For several of these proteins, the magnitude of increase in synthesis was greater for IL-1 then TNF ( $\alpha_{1}$ acid glycoprotein, $\alpha_{1}$ antichymotrypsin, and inter- $\alpha$-trypsin inhibitor). Conversely, the decrease in synthesis of transferrin was greater in the presence of TNF than in IL-1. All of the changes in rate of synthesis correspond to changes in plasma concentrations of the individual glycoproteins during acute inflammation or tissue injury (30, 31), except for that of $\mathrm{C} 4$ and $\alpha_{1}$ proteinase inhibitor. Biosynthesis of C-reactive protein or serum amyloid A component was not demonstrated in either the Hep G2 or Hep 3B cells incubated with TNF or IL-1.

The effect of TNF on biosynthesis of hepatic secretory proteins was dose related (Fig. 2). An increase in synthesis of C3

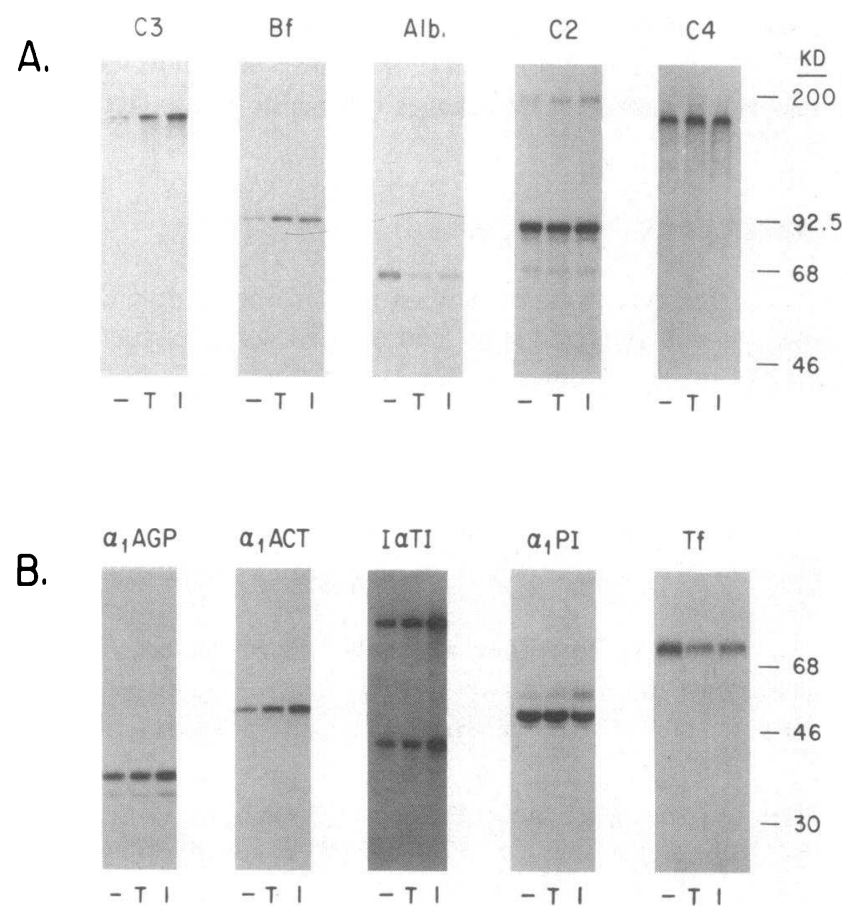

Figure 1. Effect of TNF and IL-1 on synthesis of several hepatic secretory proteins in human hepatoma cells. Hep G2 cells were incubated in medium without $(-)$ or with recombinant-generated human TNF (T) or recombinant-generated human pI $7.0 \mathrm{IL}-1$ (I), $100 \mathrm{ng} / \mathrm{ml}$, for $18 \mathrm{~h}$ and then radiolabeled for $30 \mathrm{~min}$. Radiolabeled proteins in the intracellular lysates were detected by immunoprecipitation, SDSPAGE, and fluorography. Cell number and total protein synthesis were not affected by TNF or IL-1. Molecular mass markers are indicated. Alpha-1-acid glycoprotein ( $\alpha_{1}$ AGP), alpha-1-antichymotrypsin $\left(\alpha_{1} \mathrm{ACT}\right)$, inter-alpha-trypsin inhibitor ( $\left.\mathrm{I} \alpha \mathrm{TI}\right)$, alpha-1-proteinase inhibitor $\left(\alpha_{1} \mathrm{PI}\right)$, transferrin (Tf), Bf, factor B, and Alb., albumin. 
Table I. Effect of TNF and IL-1 on Net Synthesis of Plasma Proteins in Human Hepatoma Hep G2

\begin{tabular}{lllr}
\hline & \multicolumn{3}{c}{$\begin{array}{l}\text { Percent change of } \\
\text { control }\end{array}$} \\
\cline { 3 - 3 } Plasma proteins & $n^{*}$ & TNFु & IL-18 \\
\hline Increase & & & \\
C3 & 4 & 268 & 228 \\
Factor B & 5 & 245 & 312 \\
$\alpha_{1}$ ACT & 3 & 203 & 266 \\
Decrease & & & \\
Albumin & 5 & 46 & 56 \\
Transferrin & 3 & 52 & 65 \\
Minimal change & & & \\
$\alpha_{1}$ AGP & 3 & 127 & 160 \\
I- $\alpha$-TI & 3 & 118 & 175 \\
No change & & & \\
C2 & 4 & 104 & 98 \\
C4 & 3 & 104 & 102 \\
$\alpha_{1}$ PI & 3 & 103 & 92 \\
& & &
\end{tabular}

$\alpha_{1} \mathrm{ACT}$, alpha-1-antichymotrypsin; $\alpha_{1} \mathrm{AGP}$, alpha-1-acid glycoprotein; $\alpha_{1}$ PI, alpha-1-proteinase inhibitor; I- $\alpha$-TI, inter-alpha-trypsin inhibitor.

* Number of separate experiments.

$\ddagger$ Mean values determined by direct scintillation counting of gel slices. $\S 100 \mathrm{ng} / \mathrm{ml}$; 18-h incubation.

and decrease in synthesis of albumin could be demonstrated after incubation of hepatoma cells in concentrations of TNF as low as $50 \mathrm{pg} / \mathrm{ml}\left(\sim 3 \mathrm{pM} ; \sim 4 \times 10^{4}\right.$ molecules/cell). A similar dose-dependent increase in synthesis of factor $B$ was observed (data not shown), but there was no change in synthesis of total TCA-precipitable protein or C2 at any concentration of TNF. Increases in the biosynthesis of $\mathrm{C} 3$ and factor B were not due to contamination of the TNF preparation by endotoxin, since endotoxin alone (up to concentrations of $100 \mathrm{ng} / \mathrm{ml}$ ) had no effect on the synthesis of the complement proteins in hepatoma cells (Cole, F. S., and R. C. Strunk, personal communication).

Since TNF has been shown to induce the release of IL-1

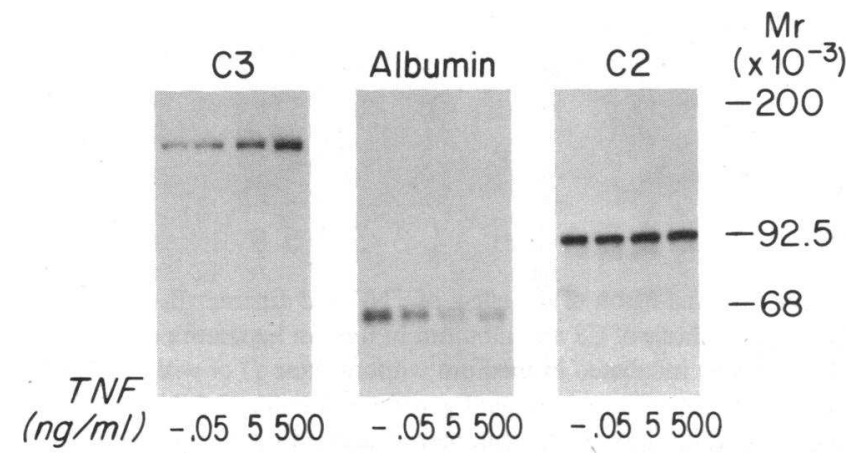

Figure 2. Dose-response relationship of TNF to synthesis of C3, albumin, and C2. Hep G2 cells were incubated in medium without (-) or with TNF in the indicated concentrations for $18 \mathrm{~h}$ and then radiolabeled for $30 \mathrm{~min}$. Radiolabeled proteins in the intracellular lysates were detected as described in Fig. 1. Molecular mass markers are indicated. from human monocytes (13), it was necessary to examine the possibility that changes in hepatic protein synthesis mediated by TNF involved induction of IL-1 expression in hepatoma cells. Human hepatoma cells (Hep G2 and Hep 3B) were incubated in control medium or medium supplemented with TNF (100 $\mathrm{ng} / \mathrm{ml}$ ) for intervals of 6-12 $\mathrm{h}$ followed by isolation of total cellular RNA. This RNA was then subjected to RNA blot analysis using human IL-1 cDNA (32) as probe and human monocyte RNA as positive control. A 1.7 kilobase (kb) mRNA was present in human monocytes but not in human hepatoma cells (data not shown). There was no evidence of IL-1 mRNA in hepatoma cells incubated with lipopolysaccharide $(1 \mu \mathrm{g} / \mathrm{ml})$. Finally, there was no evidence for synthesis of TNF in hepatoma cells incubated in control medium or medium supplemented with IL-1 or TNF (data not shown).

TNF also mediated a dose-dependent increase in biosynthesis of factor B in a stable transfected cell line (21) of mouse $L$ cells transfected with cosmid DNA bearing the human C2 and factor B genes (Fig. 3). At a concentration of $100 \mathrm{ng} / \mathrm{ml}$ of TNF or IL1 , the increase in factor B synthesis was similar. The effect of TNF on the expression of factor B after DNA-mediated gene transfer was highly selective, in that there was no change in the expression of the contiguous $\mathrm{C} 2$ gene in the transfected $\mathrm{L}$ cells. Biosynthesis of endogenous $\mathrm{C} 3$ in murine $\mathrm{L}$ cells also increased in the presence of TNF (data not shown). Endogenous synthesis of factor B was not detected in parent untransfected $\mathrm{LtK}^{-}$mouse $L$ cells incubated in medium supplemented with TNF (data not shown) or IL-1 (4). There was no effect on cell number, viability, or total TCA-precipitable protein synthesis in this cell line up to TNF concentrations of $300 \mathrm{ng} / \mathrm{ml}$, which indicated that the $\mathrm{LtK}^{-}$mutants of the mouse $\mathrm{L}$ cell lineage are relatively resistant to the cytotoxic effects of TNF.

Regulation of hepatic acute-phase gene expression by TNF is pretranslational. Total cellular RNA was isolated from hepatoma cells that had been incubated with IL-1 or TNF for $12 \mathrm{~h}$ and then subjected to RNA blot analysis. TNF mediated an increase in factor $B$ mRNA concentration and a decrease in albumin messenger RNA (mRNA) concentration (Fig. 4). At a concentration of $100 \mathrm{ng} / \mathrm{ml}$ TNF or IL-1 the changes in specific mRNA levels were similar. There was also an increase in C3 mRNA concentration, but $\mathrm{C} 2$ and $\mathrm{C} 4 \mathrm{mRNA}$ concentrations were not affected by TNF or IL-1. Changes in steady state levels of factor B, C3, and albumin mRNA were also dose dependent (data not shown).

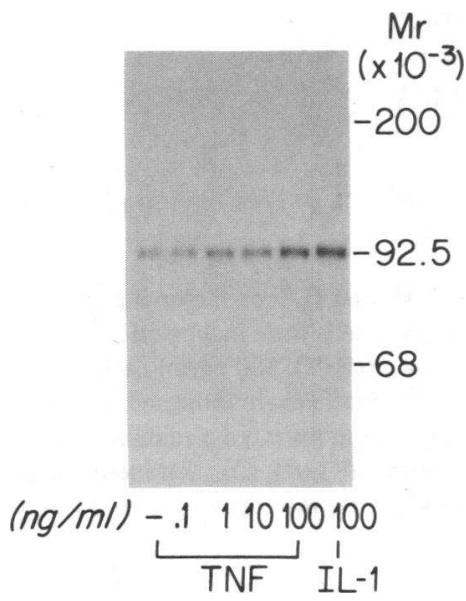

Figure 3. Effect of TNF and IL-1 on synthesis of factor $B$ in a stable transfected cell line, murine fibroblast $\mathrm{L}$ cells transfected with cosmid DNA bearing the human $C 2$, and factor $B$ genes. Confluent monolayers of transfected $\mathrm{L}$ cells were incubated without $(-)$ or with TNF or IL-1 at the indicated concentrations for $18 \mathrm{~h}$, and then radiolabeled for $30 \mathrm{~min}$. Radiolabeled factor B was detected as described in Fig. 1. Molecular mass markers are indicated. 


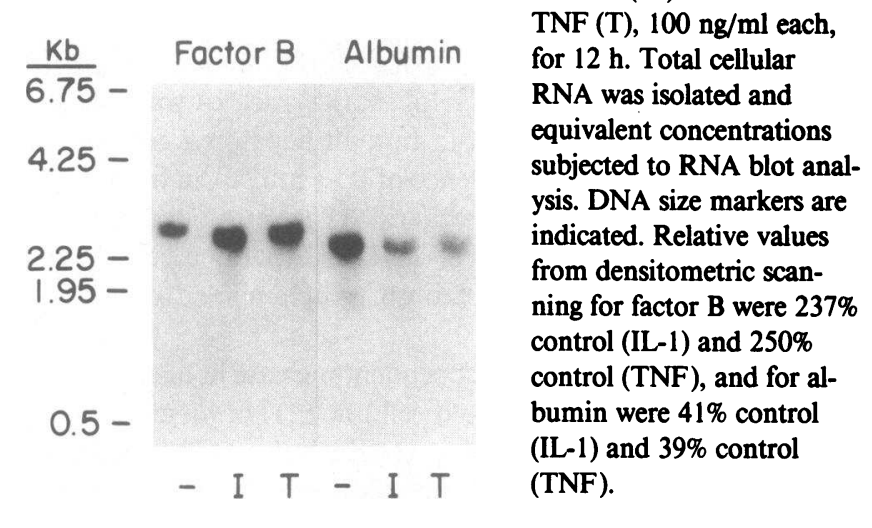

Regulation of hepatic gene expression by TNF is time dependent and reversible. Monolayers of hepatoma cells were incubated with TNF or IL-1 for several time intervals up to $24 \mathrm{~h}$. Total cellular RNA was isolated for RNA blot analysis, and biosynthetic labeling was done in parallel experiments. Factor B mRNA concentration increased between 1 and $3 \mathrm{~h}$ of incubation in IL-1 or TNF (Fig. 5). There was an unexpected decrease in factor B mRNA concentration after $1 \mathrm{~h}$ incubation in TNF on two separate blots. There was no decrease in ethidium bromide-stained $28 \mathrm{~S}$ and $18 \mathrm{~S}$ RNA or in C2 mRNA at that time on either blot. This may mean that there is an initial decrease in factor B mRNA in the presence of TNF, but by $3 \mathrm{~h}$ of incubation factor $B$ mRNA concentration consistently increases and later reaches a steady-state level comparable with that in IL-1-supplemented medium. There was not a corresponding decrease in the rate of synthesis of factor $B$ during the shortest interval of incubation in TNF-supplemental medium $(3 \mathrm{~h})$. The

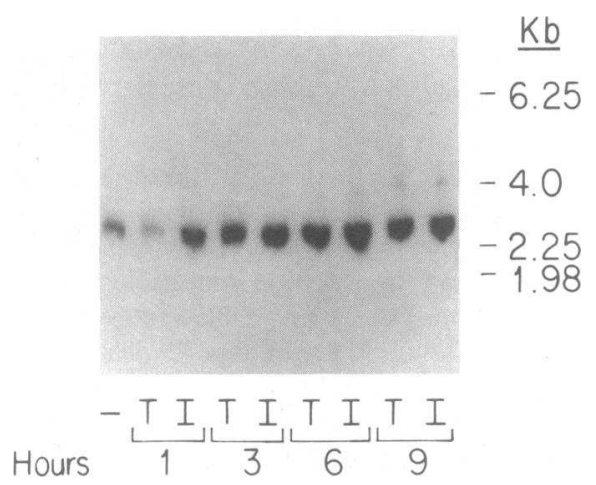

Figure 5. Kinetics of the effect of TNF and IL-1 on factor B expression in human hepatoma cells. Hep G2 cells were incubated in medium without (-) or with IL-1 (I) or TNF (T), $100 \mathrm{ng} / \mathrm{ml}$ each, for the indicated time intervals. DNA size markers are indicated. Densitometric scanning of this autoradiogram demonstrated a maximal increase in factor B mRNA concentration of $288 \%$ after 9 -h incubation in medium containing TNF and $380 \%$ after $6-\mathrm{h}$ incubation in IL-1containing medium. increase in synthesis of factor $B$ protein and decrease in synthesis of albumin were detected between 3 and $6 \mathrm{~h}$ of incubation (data not shown).

Regulation of factor B and albumin expression by TNF was also reversible. Monolayers of hepatoma cells that had been incubated with TNF for $6 \mathrm{~h}$ were rinsed and incubated without TNF for a series of time intervals up to $24 \mathrm{~h}$. Cells were then radiolabeled. Biosynthesis of factor $B$ decreased to baseline within 3-6 $\mathrm{h}$, but synthesis of albumin did not increase to baseline until 12-24 h (data not shown).

Hepatic acute-phase gene expression is mediated by TNF and multiple forms of $I L-1$. Changes in expression of factor B, C3, and albumin mediated by recombinant-generated human TNF were compared to those mediated by recombinant-generated human pI $7.0 \mathrm{IL}-1$ precursor $(24 \mathrm{kD})$, recombinant-generated human pI $7.0 \mathrm{IL}-1(17 \mathrm{kD})$, recombinant-generated human pI 5.0 IL-1, and purified human monocyte pI $7.0 \mathrm{IL}-1$ (Fig. 6). Biosynthesis of $\mathrm{C} 3$ increased and synthesis of albumin decreased in each case. The magnitude of the changes in synthesis of $\mathrm{C} 3$ and albumin were less in the case of pI $7.0 \mathrm{IL}-1$ (17 kD) and $\mathrm{pH} 5.0 \mathrm{IL}-1$. These differences in dose response could result from differences in method of isolation, relative stability of the precursor and mature forms of IL- 1 in cell culture fluid, or from primary structural differences between $\mathrm{pI} 5.0$ and $\mathrm{pI} 7.0 \mathrm{IL}-1$ polypeptides (33).

\section{Discussion}

TNF is a monokine that directly affects the functional state of several different tissues. It produces hemorrhagic necrosis of tumors in animals (5), suppresses lipid biosynthesis in adipose tissue (6-8), modulates proteolytic activity in connective tissue (14), augments granulocyte phagocytic activity (15), regulates the expression of histocompatibility antigens (34), and acts as

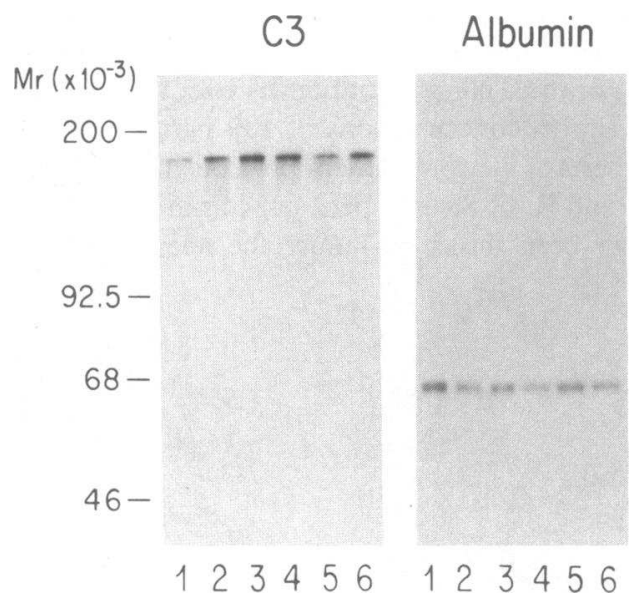

Figure 6. Comparison of the effect of TNF and different IL-1 preparations on synthesis of $\mathrm{C} 3$ and albumin in human hepatoma cells. Hep G2 cells were incubated in medium without (lane 1) or with TNF, 100 $\mathrm{ng} / \mathrm{ml}$ (lane 2), with recombinant-generated human pI $7.0 \mathrm{IL}-1$ (17 $\mathrm{kD}), 100 \mathrm{ng} / \mathrm{ml}$ (lane 3), recombinant-generated human pI $7.0 \mathrm{IL}-1$ $(24 \mathrm{kD}), 100 \mathrm{ng} / \mathrm{ml}$ (lane 4), recombinant-generated human pI 5.0 IL-1, $10 \mathrm{U} / \mathrm{ml}$ (lane 5), and with purified human monocyte pI $7.0 \mathrm{IL}$ $1,10 \mathrm{U} / \mathrm{ml}$ (lane 6), for $18 \mathrm{~h}$, and then radiolabeled for $30 \mathrm{~min}$. Radiolabeled $\mathrm{C} 3$ and albumin in intracellular lysates were detected by techniques described in Fig. 1. Molecular mass markers are indicated. 
an endogenous pyrogen (13). Many of these effects are similar to those of IL-1 and characteristic of the acute-phase response, despite substantial differences in the primary structures of TNF and IL-1. The results of this study indicate that TNF and IL-1 also have similar effects on the functional state of the liver, by mediating changes in the expression of multiple hepatic gene products. The activity of these two monokines is even more remarkable in that they individually regulated specific genes in positive (factor B, C3, $\alpha_{1}$ acid glycoprotein, $\alpha_{1}$ antichymotrypsin, and inter- $\alpha$-trypsin inhibitor) and negative (albumin, transferrin) directions.

In addition to differences in primary structure, TNF and IL1 are recognized by distinct cell surface receptors in at least one cell type that has been examined, namely cultured adipocytes (18). If these two molecules are also recognized by different receptors on the surface of hepatocytes it would mean that regulation of several discrete genes in a similar fashion is elicited by two different signal recognition systems. Transduction of a common second signal, or triggering of a common transcriptional or posttranscriptional processing mechanism by different second messengers, could explain these observations.

Several characteristics of TNF suggest that in vivo it may be an important, if not dominant, mediator of the hepatic acutephase response. First, radiolabeled TNF is concentrated in the liver after intravenous administration (35). Second, TNF may be released in higher concentrations than IL-1 under certain circumstances; e.g., rabbits injected with endotoxin (35). Third, TNF mediates changes in hepatic gene expression in hepatoma cells that appear to express only small numbers of TNF receptors (36). An increase in TNF receptor number resulting from the action of other mediators released during acute inflammation may further augment the hepatic effects of TNF. Interferon- $\gamma$, for example, increases TNF receptor number two to threefold in a cervical carcinoma cell line (37). Finally, the effect of TNF in vivo may be amplified by autocrine, or paracrine, stimulation of IL-1 release (13).

The mechanism of regulation of hepatic acute-phase gene expression by TNF and IL-1 is likely to be transcriptional. Changes in specific mRNA concentrations presented here represent steady state levels, or the balance between transcription and mRNA turnover. However, Kulkarni et al. have shown that changes in the expression of $\alpha_{1}$ acid glycoprotein and albumin in rat liver after subcutaneous turpentine injection primarily reflect changes in rate of transcription (38). Further studies will be necessary to prove that transcriptional regulation is elicited by highly purified monokines, IL-1 and TNF, and to determine whether the same mechanism can be implicated in their effects on different hepatic gene products. Plasma concentrations of $\mathrm{C} 4$ and $\alpha_{1}$ proteinase inhibitor increase during acute inflammation but synthesis of these hepatic secretory proteins in human hepatoma cells is not affected by IL-1 or TNF. It is possible that posttranslational processing, secretion, and/or extracellular turnover are important levels of control for these and other hepatic secretory proteins during acute inflammation.

These experiments indicate that hepatic acute-phase gene expression can result from the direct action of two distinct monokines, but do not exclude the possibility that other mediators are involved. A hepatocyte-stimulating factor, which appears to be distinct from IL-1 (39), and lymphotoxin, which shares $>40 \%$ homology with TNF (12) and occupies the same receptor as TNF (36), are likely candidates.

\section{Acknowledgments}

The authors thank Barbara Brescia for secretarial assistance.

This study was supported in part by an award from the Charles $\mathrm{H}$. Hood Foundation, by an American Gastroenterological Association/ Merck, Sharp and Dohme Research Scholar Award, and by U. S. Public Health Service grants HD17461, AI20032, AI20959, and AI15614.

\section{References}

1. Dinarello, C. A. 1984. Interleukin-1 and the pathogenesis of the acute phase response. N. Engl. J. Med. 311:1413-1418.

2. Dinarello, C. A. 1985. An update on human interleukin-1: from molecular biology to clinical relevance. J. Clin. Immunol. 5:287-297.

3. Ramadori, G., J. D. Sipe, C. A. Dinarello, S. B. Mizel, and H. R. Colten. 1985. Pretranslational modulation of acute phase hepatic protein synthesis by murine recombinant interleukin-1 (IL-1) and purified human IL-1. J. Exp. Med. 162:930-942.

4. Perlmutter, D. H., G. Goldberger, C. A. Dinarello, S. B. Mizel, and H. R. Colten. 1986. Regulation of class III major histocompatibility complex gene products by interleukin 1. Science (Wash. DC). 232:850852.

5. Old, L. J. 1985. Tumor necrosis factor (TNF). Science (Wash. DC). 230:630-632.

6. Kawakami, M., P. H. Pekala, M. D. Lane, and A. Cerami. 1982. Lipoprotein lipase suppression in 3T3-L1 cells by an endotoxin-induced mediator from exudate cells. Proc. Natl. Acad. Sci. USA. 79:912-916.

7. Pekala, P. H., M. Kawakami, C. W. Argus, M. D. Lane, and A. Cerami. 1983. Selective inhibition of synthesis of enzymes for de novo fatty acid biosynthesis by an endotoxin-induced mediator from exudate cells. Proc. Natl. Acad. Sci. USA. 80:2743-2747.

8. Torti, F. M., B. Dieckmann, B. Beutler, A. Cerami, and G. M. Ringold. 1985. A macrophage factor inhibits adipocyte gene expression: an in vitro model of cachexia. Science (Wash. DC). 229:867-869.

9. Beutler, B. D., D. Greenwald, J. D. Holmes, M. Chang, Y.-C. E. Pan, J. Mathison, R. Ulevitch, and A. Cerami. 1985. Identity of tumor necrosis factor and the macrophage-secreted factor cachectin. Nature (Lond.). 316:552-554.

10. Carswell, E. A., L. J. Old, R. L. Kassel, S. Green, N. Fiore, and B. Williamson. 1975. An endotoxin-induced serum factor that causes necrosis of tumors. Proc. Natl. Acad. Sci. USA. 72:3666-3670.

11. Aggarwal, B. B., W. J. Kohr, P. E. Hass, B. Moffat, S. A. Spencer, W. J. Henzel, T. S. Bringman, G. E. Nedwin, D. V. Goeddel, and R. N. Harkins. 1985. Human tumor necrosis factor. Production, purification and characterization. J. Biol. Chem. 260:2345-2354.

12. Pennica, D., G. E. Nedwin, J. S. Hayflick, P. H. Seeburg, R. Derynck, M. A. Palladino, W. J. Kohr, B. B. Aggarwal, and D. V. Goeddel. 1984. Human tumor necrosis factor: precursor structure, expression and homology to lymphotoxin. Nature (Lond.). 312:724-729.

13. Dinarello, C. A., J. G. Cannon, S. M. Wolff, H. A. Bernheim, B. Beutler, A. Cerami, I. S. Figari, M. A. Palladina, and J. V. O'Connor. 1986. Fever, tumor necrosis factor/cachectin and interleukin-1. J. Exp. Med. 163:1433-1450.

14. Dayer, J. M., B. Beutler, and A. Cerami. 1985. Cachectin/tumor necrosis factor stimulates collagenase and prostaglandin $\mathrm{E}_{2}$ production by human synovial cells and dermal fibroblasts. J. Exp. Med. 162:21632168.

15. Shalaby, M. R., B. B. Aggarwal, E. Rinderknecht, L. P. Svedersky, B. S. Finkle, and M. A. Palladino. 1985. Activation of human polymorphonuclear neutrophil function by interferon- $\gamma$ and tumor necrosis factors. J. Immunol. 135:2069-2073.

16. Lovett, D., B. Kozan, M. Hadam, K. Resch, and D. Gemsa. 1985. Macrophage cytotoxicity: interleukin-1 as a mediator of tumor cytostasis. J. Immunol. 136:340-347.

17. Onozaki, K., K. Matsushima, B. B. Aggarwal, and J. J. Oppenheim. 1985. Interleukin-1 as a cytocidal factor for several tumor cell lines. J. Immunol. 135:3962-3968.

18. Beutler, B., and A. Cerami. 1985. Recombinant interleukin-1 
suppresses lipoprotein lipase activity in 3T3-L1 cells. J. Immunol. 135: 3969-3971.

19. Dinarello, C. A., L. Renfer, and S. M. Wolff. 1977. Human leukocytic pyrogen: purification and development of a radioimmunoassay. Proc. Natl. Acad. Sci. USA. 74:4623-4627.

20. Perlmutter, D. H., F. S. Cole, G. Goldberger, and H. R. Colten. 1984. Distinct primary translation products from human liver mRNA give rise to secreted and cell-associated forms of complement protein C2. J. Biol. Chem. 259:10380-10385.

21. Perlmutter, D. H., H. R. Colten, D. Grossberger, J. Strominger, J. G. Seidman, and D. D. Chaplin. 1985. Expression of complement proteins $\mathrm{C} 2$ and factor B in transfected L cells. J. Clin. Invest. 76:14491454.

22. Roberts, B. E., and B. M. Patterson: 1973. Effect of translation of tobacco mosaid virus RNA and rabbit globin 6sRNA in a cell-free system from commercial wheat germ. Proc. Natl. Acad. Sci. USA. 70: 2330-2334.

23. Laemmli, U. K. 1970. Cleavage of structural proteins during the assembly of the head of bacteriophage T4. Nature (Lond.). 227:690-695.

24. Chirgwin, T. M., A. E. Przybyla, R. J. MacDonald, and W. J. Rutter. 1979. Isolation of biologically active ribonucleic acid from sources enriched in ribonuclease. Biochemistry. 18:5294-5301.

25. Thomas, P. 1980. Hybridization of denatured RNA and small DNA fragments transferred to nitrocellulose. Proc. Natl. Acad. Sci. USA. 77:5201-5205.

26. Woods, D. E., A. Markham, A. Ricker, G. Goldberger, and H. R. Colten. 1982. Isolation of cDNA clones for human complement protein factor B, a class III major histocompatibility complex gene product. Proc. Natl. Acad. Sci. USA. 80:4464-4468.

27. Woods, D. E., M. D. Edge, and H. R. Colten. 1984. Isolation of cDNA clone for the human complement protein $\mathrm{C} 2$ and its use in the identification of restriction fragment length polymorphism. J. Clin. Invest. 74:634-639.

28. Strunk, R. C., A. S. Whitehead, and F. S. Cole. 1985. Pretranslational regulation of the synthesis of the third component of complement in human mononuclear phagocytes by the lipid A portion of lipopolysaccharide. J. Clin. Invest. 76:985-990.

29. Kurnit, D. M., B. W. Philipp, and G. A. P. Bruns. 1982. Confirmation of the mapping assignment of human serum albumin to chro- mosome 4 using a cloned human albumin gene. Cytogenet. Cell Genet. 34:284-289.

30. Aronsen, K.-F., G. E. Ekelund, C.-O. Kindmark, and C.-B. Laurell. 1972. Sequential changes of plasma proteins after surgical trauma. Scand. J. Clin. Lab. Invest. 29:127-135.

31. Johansson, B. G., C.-O. Kindmark, E. Y. Trell, and F. A. Wollheim. 1972. Sequential changes of plasma proteins after myocardial infarction. Scand. J. Clin. Lab. Invest. 29:117-126.

32. Auron, P. E., A. C. Webb, L. J. Rosenwasser, S. F. Mucci, A. Rich, S. M. Wolff, and C. A. Dinarello. 1984. Nucleotide sequence of human monocyte interleukin-1 precursor cDNA. Proc. Natl. Acad. Sci. USA. 81:7907-7911.

33. March, C. J., B. Mosly, A. Laren, D. P. Ceretti, G. Braedt, V. Price, S. Gillis, C. S. Henney, S. R. Kronheim, K. Grabstein, P. J. Conlon, T. P. Hopp, and D. Cosman. 1985. Cloning, sequence and expression of two distinct interleukin-1 complementary DNAs. Nature (Lond.). 315: 641-647.

34. Collins, T., L. A. Lapierre, W. Fiers, J. L. Strominger, and J. S. Pober. 1986. Recombinant human tumor necrosis factor increases mRNA levels and surface expression of HLA-A,B antigens in vascular endothelial cells and dermal fibroblasts in vitro. Proc. Natl. Acad. Sci. USA. 83:446-450.

35. Beutler, B. A., I. W. Milsark, and A. Cerami. 1985. Cachectin/ tumor necrosis factor: production, distribution and metabolic rate in vivo. J. Immunol. 135:3972-3977.

36. Kull, F. C., S. Jacobs, and P. Cuatrecasas. 1985. Cellular receptor for ${ }^{125}$ I-labeled tumor necrosis factor: specific binding, affinity labeling, and relationship to sensitivity. Proc. Natl. Acad. Sci. USA. 82:57565760.

37. Aggarwal, B. B., T. E. Essalu, and P. E. Hass. 1985. Characterization of receptors for human tumor necrosis factor and their regulation by $\gamma$-interferon. Nature (Lond.). 318:665-667.

38. Kulkarni, A. B., R. Reinke, and P. Feigelson. 1985. Acute phase mediators and glucocorticoids elevate $\alpha$-1-acid glycoprotein gene transcription. J. Biol. Chem. 260:15386-15389.

39. Wolosky, B. N. R. N. J., and G. M. Fuller. 1985. Identification and partial characterization of hepatocyte-stimulating factor from leukemic cell lines: comparison with interleukin-1. Proc. Natl. Acad. Sci. USA. 82:1443-1447. 